\title{
Utjecaj primjene Amadea $u$ neurorehabilitaciji ruke kod osoba nakon moždanog udara
}

1 Mark Tomaj

2 Mile Marinčić

1 Poliklinika Glavić Zagreb

2 Visoka škola Ivanić-Grad

\section{Sažetak}

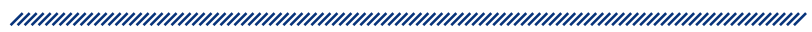

Uvod: Moždani je udar oboljenje moždanih struktura, što rezultira smanjenom mogućnošću kretanja, smetnjama u koordinaciji pokreta i hoda. Treći je uzrok smrtnosti u svijetu, a drugi uzrok smrtnosti u Hrvatskoj. Osobe koje su preboljele moždani udar znaju imati teška oštećenja te ograničenosti kretanja i probleme s percepcijom. lako se kod rehabilitacije osoba koje su imale moždani udar najviše primjenjuju tradicionalne metode rehabilitacije, danas se u neurorehabilitaciji sve više primjenjuje robotika. Robotika u neurorehabilitaciji osoba nakon moždanog udara ima svoje mjesto u rehabilitacijskom protokolu. Cilj je neurorobotike potpomognuta rehabilitacija za gornje i donje ekstremitete u svrhu oporavka oštećene motorike kako bi pružala pomoć bolesnicima u obavljanju svakodnevnih aktivnosti. Ovim smo radom ispitali utjecaj robotskoga terapijskog uređaja Amadeo na rehabilitaciju funkcije šake. Glavni je cilj robotskog terapijskog uređaja Amadeo usmjerena vježba dostizanja zadataka sa stalnim povećanjem intenziteta i broja ponavljanja. Rad će upozoriti i na moguće etičke probleme s kojima se suvremena medicina susreće, pogotovo kad je u pitanju primjena suvremene tehnologije u rehabilitacijskim procesima. Ovo je nabačaj etičkog osvrta u radu i postavlja otvorena pitanja za daljnja istraživanja u budućnosti.

Cilj rada: Ispitati učinak robotskog terapijskog uređaja Amadeo na povećanje opsega pokreta i snage, smanjenje tonusa i spazma u šaci kod osoba nakon moždanog udara.

Metode: Za provjeru uspješnosti provedena su mjerenja na početku i na kraju terapije robotskim terapijskim uređajem Amadeo. Mjerenja se odnose na opseg pokreta, snagu, tonus i spazam po modificiranoj Ashworthovoj skali.

Rezultati i zaključci: Rezultati mjerenja snage šake pokazali su statistički značajnu razliku između rezultata mjerenja na početku i kraju terapije. Robotski terapijski uređaj Amadeo siguran je i često se primjenjuje za klinička istraživanja.

Ključne riječi: moždani udar, neurorehabilitacija, etika robotika, robotski terapijski uređaj Amadeo

Datum primitka: 11.09.2018.

Datum prihvaćanja: 20.10.2018.

DOI: $10.24141 / 1 / 4 / 2 / 11$

Adresa za dopisivanje:

Mark Tomaj

Poliklinika Glavić Zagreb, Radnička cesta 54, Zagreb, Hrvatska E-pošta: mark.tomaj@gmail.com 


\section{Uvod}

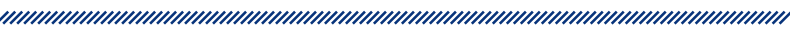

Svjetska zdravstvena organizacija moždani udar definira kao klinički sindrom uzrokovan cerebrovaskularnim poremećajem cirkulacije što onemogućava opskrbu određenih dijelova mozga kisikom i hranjivim tvarima. ${ }^{1}$ Oštećenje i odumiranje živčanih stanica u dijelovima mozga prouzročeno nedostatkom kisika i hranjivih tvari posljedično oštećuje one funkcije kojima ti dijelovi mozga upravljaju. ${ }^{2}$

Najčešći su uzrok smrti u Hrvatskoj ishemijske bolesti srca, a nakon toga slijede cerebrovaskularne bolesti s udjelom od $14 \%$ te je 2013. godine zabilježeno da je umrlo 7243 osobe. Kada se ti podaci raspodijele po županijama, ukupan broj umrlih od $53 \%$ bilježi Istarska županija, dok Primorsko-goranska županija ima najmanji udio od $44 \%$. Stopa smrtnosti koja je dobno standardizirana za bolesti cerebrovaskularnog sustava u Republici Hrvatskoj iznosila je 103 na 100000 stanovnika za 2011. godinu, za razliku od Austrije, gdje je stopa smrtnosti gotovo tri i pol puta niža i iznosila je 30 na 100000 stanovnika, te Mađarske, gdje je zabilježeno 83 na 100000 stanovnika. U Europskoj uniji stopa smrtnosti upola je niža te je iznosila 50 na 100000 stanovnika. ${ }^{1}$

\section{Neurorehabilitacija}

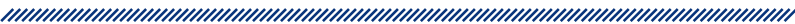

Neurorehabilitacija se inače započinje kada je pacijent u stabilnom stanju jer se oporavak funkcije najviše može iskoristiti u prva tri mjeseca nakon moždanog udara. Općepoznato je da pacijent može trajno izgubiti funkcije kojima se ne koristi te da je motivacija pacijenta vrlo važna za uspješnu terapiju. Kako bi pacijent mogao dobiti novu funkciju, važan je velik broj ponavljanja, intenzitet i specifičnost podražaja, vrijeme trajanja podražaja te važnost određene funkcije za pacijenta. Pacijent uz terapeuta mora aktivno sudjelovati tijekom kretnji i započeti pokret. Kada je intenzitet podražaja i broj ponavljanja kretnji veći, neuroplastičnost je veća. Neuroplastičnost djeluje kao posljedica novih podražaja za pojedine funkcije koja može poboljšati funkcije i oporavak sličnih funkcija. ${ }^{1}$
Aspekti neurorehabilitacije, osim medicinskog pristupa, mogu biti psihosocijalni i radni. Najčešći medicinski pristup obuhvaća razne terapije motoričkih, senzornih te kognitivnih oštećenja koja su nastala nakon moždanog udara. Psihosocijalni pristup bavi se poteškoćama reintegracije pacijenata u svoju obitelj i društvo ili prilagodbu društvu invalidnih osoba. Radni aspekti ovise o razini onesposobljenosti osobe. Nastoji se uključiti svaku osobu u razne programe radne rehabilitacije ili prekvalifikacije kako bi i dalje mogla biti aktivan član zajednice. Stoga u rehabilitacijskom timu najčešće sudjeluje više stručnjaka; specijalist fizijatrijske medicine, fizioterapeut, radni terapeut, medicinska sestra, liječnici ostalih specijalnosti, logoped i psiholog. ${ }^{1}$ Iznimno je važno da se kroz etičke kodekse institucija unutar kojih se osigurava rehabilitacija osigura etički pristup pacijentu po načelima personalističke etike poštujući integritet svake osobe, o čemu se u suvremenoj medicini i liječenju sve češće govori kroz vid personalizirane medicine, posebice u izlaganjima bivšeg ministra Dragana Primorca. ${ }^{3,4} \mathrm{U}$ tom kontekstu dobro je uzeti u obzir i usvojene tekstove Europskog parlamenta o Pravilima građanskog prava o robotici. U navedenom dokumentu jasno stoji kako se uzima u obzir studija pod nazivom Etički aspekti kibernetičko-fizičkih sustava. Isto se tako konstatira kako se ljudska vrsta nalazi na pragu razdoblja u kojem je sve više sofisticiranih robota, botova, androida i drugih oblika umjetne inteligencije spremno za novu industrijsku revoluciju koja će vrlo vjerojatno utjecati na sve slojeve društva te je od ključne važnosti da zakonodavac razmotri njezine pravne i etičke implikacije i učinke bez kočenja inovacija. U općim načelima dokumenta upozorava se na potrebu početka rada po pitanju građanskopravne odgovornosti, zatim slijedi razrada pojma odgovornost, kao i etičkih načela. Poseban naglasak stavlja se na „robote za njegu”, „medicinske robote” te robote za „popravljanje” organa i „poboljšavanje" ljudskog tijela. U prilogu rezoluciji posebno se naglašava i preporuka o sadržaju traženoga predmeta kroz povelju o robotici, kodeks etičkoga ponašanja za inženjere robotike, kodeks povjerenstva za istraživačku etiku, uz dozvole za projektante i korisnike. Mišljenja smo kako navedeni dokumenti uistinu mogu pomoći što je moguće etičnijoj i transparentnijoj primjeni robotike u biomedicini uopće. ${ }^{5}$ 


\section{Robotika u neurorehabilitaciji}

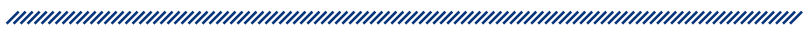

Primjena robota prisutna je u svima područjima ljudske djelatnosti i smatra se da je to jedan od najvažnijih pravaca razvoja čovječanstva u 21. stoljeću. Primjena robota u medicini (dijagnostika, kirurgija, skrb o bolesnicima, rehabilitacija i sl.) nije bila znatnije zastupljena u praksi, a danas je to jedno od najperspektivnijih područja u koje se ulažu znatna financijska sredstva i znanstveni resursi te se očekuju skori važni rezultati. ${ }^{6}$

Postoje velike prednosti robota u revolucionarnoj kliničkoj praksi. Roboti olakšavaju medicinske procese uz precizno vođenje instrumenata te primjenu dijagnostičkih uređaja i alata za terapije. Utječu na povećanje sigurnosti i ukupne kvalitete operacije i bolju njegu bolesnika. Često se primjenjuju za edukaciju i osposobljavanje medicinskog osoblja te promociju korištenja informacijama u dijagnostici i terapiji. Svrha je da se stvaraju medicinski roboti koji zadovoljavaju prave potrebe u području medicinske pomoći i u području njege čovjeka, gdje je potrebna visoka razina tehnologije. Upotreba takve vrste robota sljedećih generacija bit će promovirana za rehabilitacijska područja u kojima roboti imaju više fizičkog kontakta s pacijentima, a osigurana je sigurnost čovjeka. ${ }^{7}$

Gledajući etičku stranu upotrebe robota u rehabilitacijskom procesu svakako bi trebalo imati na pameti kako je robot (robotika) prvenstveno pomoć stručnom i osposobljenom osoblju kako bi proces rehabilitacije bio što je moguće brži i kvalitetniji. Sve je navedeno jasno definirano i u spomenutim dokumentima koje je usvojio Europski parlament: P8_TA(2017)0051 Pravila građanskog prava o robotici, Rezolucija Europskog parlamenta od 16. veljače 2017. s preporukama Komisiji o pravilima građanskog prava o robotici $\left(2015 / 2103\left(\right.\right.$ INL)). ${ }^{5}$ Samo možemo promišljati kamo će nas odvesti umjetna inteligencija i što bi se moglo dogoditi s ljudskom mudrošću u tom kolopletu zbivanja u budućnosti. Možemo se nadati da će ljudska mudrost u zajedništvu s moralom, etikom i bioetikom moći, htjeti i znati postaviti prave orijentire u primjeni i ophođenju sa suvremenom tehnologijom.

\section{Robotski terapijski uređaj amadeo}

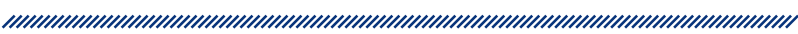

Robotski terapijski uređaj Amadeo jedan je od najnovijih u nizu klinički testiranih robotskih i kompjuterskih terapijskih uređaja za ruku i prste. Namijenjen je za terapiju šake i prstiju bolesnika s neurološkim oštećenjem središnjega živčanog sustava s tipičnim indikacijama kao što su moždani udar ili traumatska ozljeda mozga. Robotski terapijski uređaj Amadeo najviše se primjenjuje u ergoterapiji i fizioterapiji uz konvencionalne terapijske metode. Ponavljajuće kretnje zglobova prstiju stvaraju intrinzične i ekstrinzične podražaje koji pogoduju reorganizaciji mozga. Ponavljajuća aktivna vježba i trening potiče neuronsku plastičnost i time promjene ili prilagodbe sinapsi, živčanih stanica ili čak cjelokupnih cerebralnih područja kako bi se vratili izgubljeni pokreti. ${ }^{8}$

\subsection{Indikacije Amadea}

- moždani udar (hemoragijski, ishemijski)

- traumatsko oštećenje mozga (TBI)

- ozljede kralježnične moždine

- tumori mozga

- Parkinsonova bolest

- kronične bolesti

- cerebralna paraliza

- bolesti motoričkih neurona

- meningitis, encefalitis

- mišićna distrofija

- znakovi paralize uzrokovani u vratnoj kralježnici

- frakture i ozljede gornjih distalnih ekstremiteta.

\subsection{Apsolutne kontraindikacije:}

- akutni i određeni bolni simptomi usprkos konvencionalnoj terapiji za oštećene gornje ekstremitete

- prilagodba i pozicija pacijenta - ne smije se provoditi trening s uređajem ako individualno namještanje pacijenta u fiziološkoj poziciji nije moguće, osobito u slučajevima kontrakture ili velika spastičnost (fiksirani/rigidni zglob) gornjih ekstremiteta

- sustav robotskoga terapijskog uređaja Amadeo nije primjeren za djecu mlađu od tri godine (rizik od gutanja malih dijelova, potpore za prste) 
- nedovoljna usklađenost; djeca i pacijenti s teškim psihotičnim ili neurotičnim poremećajima

- visoki stupanj/razina ataksije

- uznapredovala osteoporoza: rizik od frakture

- frakture: ne počinje se trening u slučaju nestabilne ili nedovoljno pročišćene frakture.

\section{Cilj istraživanja}

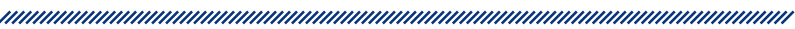

Ispitati utjecaj robotskoga terapijskog uređaja Amadeo na povećanje opsega pokreta i snage te smanjenje tonusa i spazma u šaci kod osoba nakon moždanog udara.

\section{Hipoteze}

Hipoteza 1: Robotski terapijski uređaj Amadeo ima pozitivan učinak na povećanje opsega pokreta i snage u šaci kod osoba nakon moždanog udara.

Hipoteza 2: Robotski terapijski uređaj Amadeo ima pozitivan učinak na smanjenje tonusa i spazma u šaci kod osoba nakon moždanog udara.

\section{Metode rada}

\subsection{Uzorak ispitanika}

Istraživanje je provedeno u Poliklinici Glavić Zagreb i Dubrovnik na 16 bolesnika koji su imali moždani udar. Svi su bolesnici prolazili rehabilitacijski program koji je bio individualno prilagođen za osobe s hemiparezom u trajanju od 45 minuta na robotskom terapijskom uređaju Amadeo svaki dan uz stalnu superviziju fizioterapeuta. Navedeni se rehabilitacijski program provodio šest dana u tjednu. Treba napomenuti da su svi ispitanici u ovom istraživanju bili podvrgnuti standardnom programu fizioterapije u smislu provođenja vježbi istezanja, vježbi balansa i propriocepcije te radnoj terapiji.
Svaki je od ispitanika prije testiranja bio medicinski stabilan i sposoban pratiti osnovne verbalne upute tijekom testiranja bez rizika od padova. Tijekom testiranja ispitanici nisu imali senzacija (bol, slabost, umor ili malaksalost) koje bi utjecale na rezultat testiranja. Prije provođenja istraživanja jasno su postavljeni kriteriji za uključivanje ili isključivanje ispitanika iz istraživanja. Fizioterapeut je provodio mjerenje, inicijalno i finalno, dajući upute i promatrajući izvedbu te uređaj i zabilježio rezultate svakog zadatka. U skladu s postavljenim ciljem i metodama istraživanja, posebno se ističu etički aspekti istraživanja s naglaskom osiguravanja podataka, kao i zaštita identiteta sudionika s naglaskom upotrebe dobivenih podataka u svrhu izrade rada.

\subsection{Mjerni instrumenti $i$ varijable procjene}

Za provjeru učinka terapije među ispitanicima mjerena je snaga šake, tonus, opseg pokreta i spasticitet $u$ inicijalnom i finalnom mjerenju. Za svaki su prst pojedinačno vidljiva mjerenja na uređaju. Nad svim ispitanicima proveden je isti postupak procjene. Fizioterapeut pravilno pozicionira pacijenta uz uređaj i zatim nosače za palac i prste pričvrsti za prste pacijenta posebnim flasterima koji se prilagođavaju svakom pacijentu.

\subsection{Metode statističke obrade podataka}

Svi prikupljeni kategorički podaci predstavljeni su apsolutnim i relativnim frekvencijama, dok su numerički podaci opisani aritmetičkom sredinom i standardnom devijacijom te medijanom i interkvartilnim rasponom. Rezultati su prezentirani grafički i tablično.

\section{Rezultati}

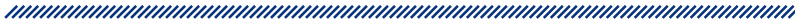

Pacijenti su bili prosječne dobi od 51,2 $\pm 11,9$ (aritmetička sredina \pm standardna devijacija) godina, gdje je najmlađi pacijent imao 30, a najstariji 76 godina. Neznatno je više bilo pacijenata ženskog spola, njih 9/16 (hi-kvadrat test; $P=0,73$ ) te je većina pacijenata, njih $12 / 16$, liječila desnu ruku (hi-kvadrat test; $P=0,06$ ).

U prosjeku su prošle dvije (medijan) godine između vremena moždanog udara i početka rehabilitacije, uz interkvartilni raspon od jedne do dvije godine. Za neke pacijente nije prošla ni godina dana između moždanog 
udara i rehabilitacije, dok je najviše kod jednog pacijenta prošlo 13 godina. Ispitanici su bili u različitom periodu uključeni u rehabilitaciju Dobiveni rezultati su prezentirani kroz zbroj ukupne sile pojedinog prsta.

Medijan prosječne snage šake prije rehabilitacije iznosi 2,3 kg uz interkvartilni raspon od 1,15 do 4,1 kg, dok je poslije rehabilitacije prosječna snaga šake znatno veća (Wilcoxonov test; $P=0,02$ ), medijan iznosi $3,45 \mathrm{~kg}$ uz interkvartilni raspon od 2,75 do 5,5 kg (slika 1).

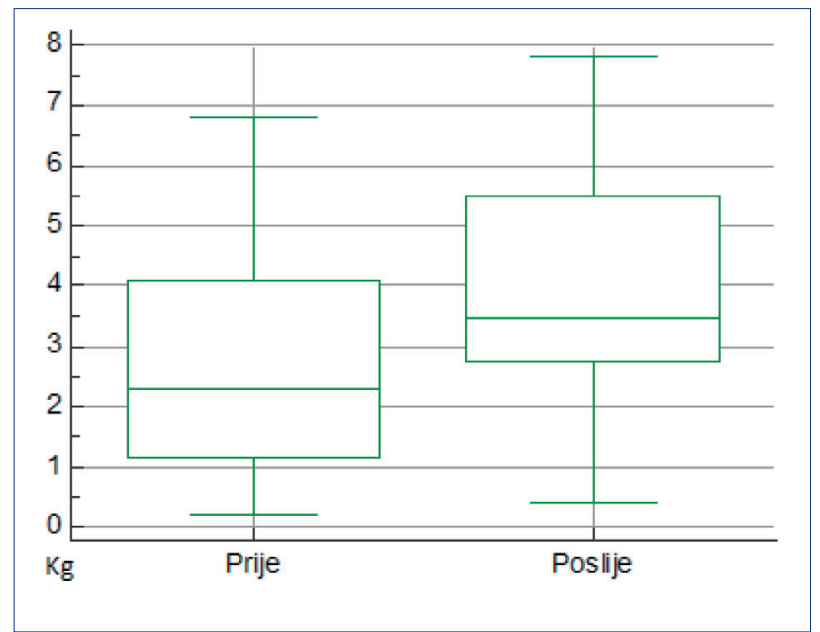

Slika 1. Usporedba snage šake prije i poslije rehabilitacije

Medijan opsega pokreta prije rehabilitacije iznosi 3,1 \% uz interkvartilni raspon od 1,25 do $27,0 \%$, dok je poslije rehabilitacije opseg pokreta šake nešto manji (Wilcoxonov test; $P=0,82$ ), medijan iznosi $2,2 \%$ uz interkvartilni raspon od 0,95 do $26,75 \%$ (slika 2 ).

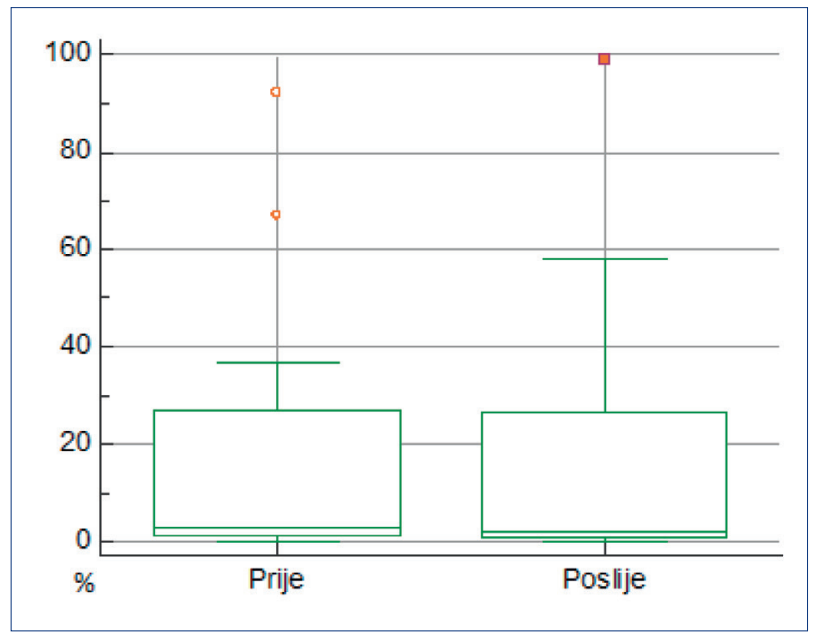

Slika 2. Usporedba opsega pokreta ruke prije i poslije rehabilitacije
Medijan tonusa prije rehabilitacije iznosi $2,5 \mathrm{~kg}$ uz interkvartilni raspon od 1,24 do $4,8 \mathrm{~kg}$, dok je poslije rehabilitacije tonus nešto manji (Wilcoxonov test; $\mathrm{P}=0,38$ ), medijan iznosi $1,65 \mathrm{~kg}$ uz interkvartilni raspon od 0,63 do $3,7 \mathrm{~kg}$ (slika 3).

Medijan spazma prije rehabilitacije iznosi 2,2 po modificiranoj Ashworthovoj skali uz interkvartilni raspon od 1,7 do 4,0 po modificiranoj Ashworthovoj skali, dok je poslije rehabilitacije spazam nešto veći (Wilcoxonov test; $P=0,57$ ), medijan iznosi 3,0 uz interkvartilni raspon od 1,0 do 4,0 (slika 4).

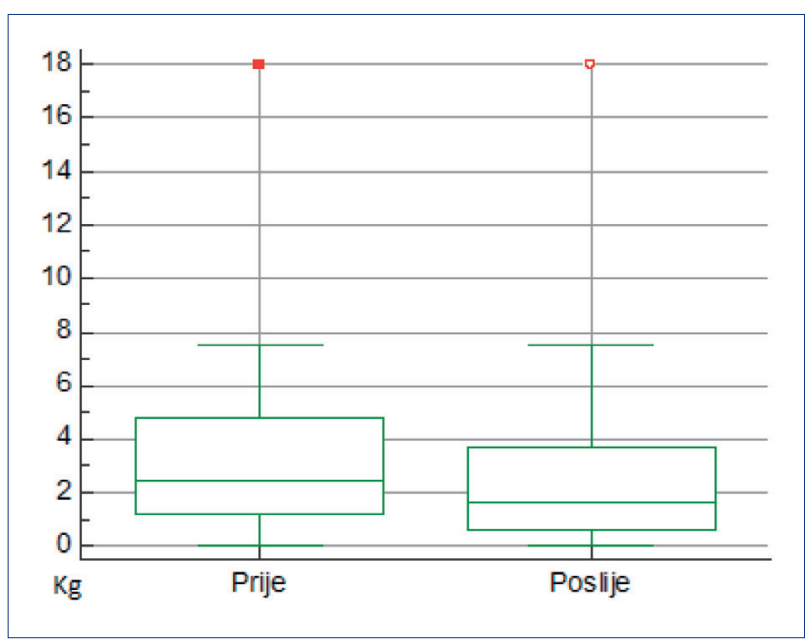

\section{Slika 3. Usporedba tonusa prije i poslije rehabilitacije}

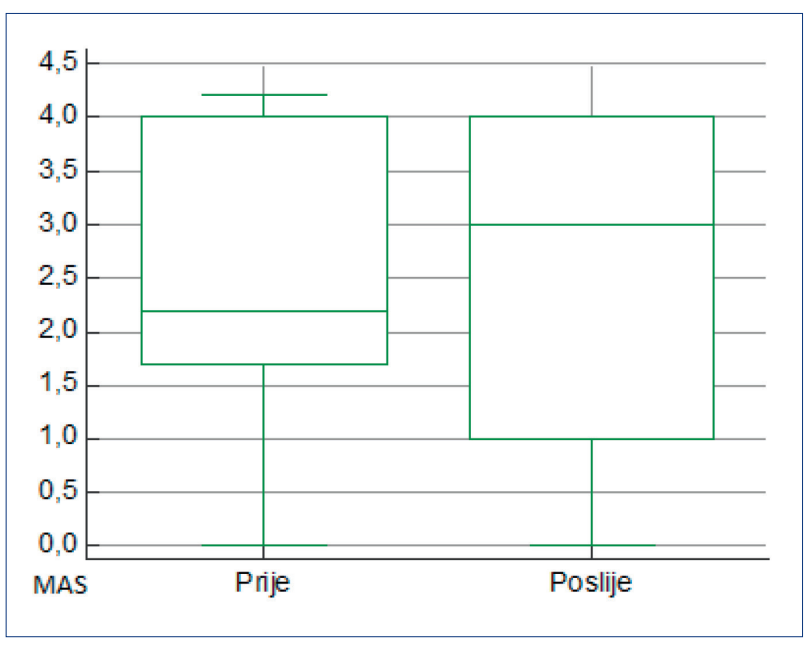

Slika 4. Usporedba spazma prije i poslije rehabilitacije 


\section{Rasprava}

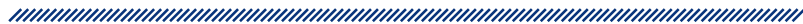

Provedeno istraživanje pokazalo je kako je utjecaj robotskoga terapijskog uređaja Amadeo na povećanje snage imao pozitivan učinak, dok povećanje opsega pokreta te smanjenje tonusa i spazma u šaci kod osoba nakon moždanog udara nije pokazalo statistički značajne razlike. Statistički značajna razlika utvrđena je za voljan, kontroliran, aktivan pokret snage šake. Uočljive su velike razlike u prosječnom napretku na početku rehabilitacije, kada je medijan prosječne snage šake iznosio 2,3 kg, dok je na kraju rehabilitacijskog programa snaga šake znatno veća, medijan $3,45 \mathrm{~kg}$. Udio ispitanika kod kojih je zabilježen napredak u terapiji bio je 12/16. Takve podatke potvrđuje istraživanje iz 2013. godine koje su proveli Pinter i suradnici o utjecaju terapijskog uređaja Amadeo gdje se snaga šake znatno povećala nakon rehabilitacije $(P<0.05)$. Provedeno je 15 terapija na robotskom uređaju Amadeo gdje je svaka trajala 20 minuta te je prosjek vježbe stiska iznosio 3600 puta. ${ }^{9}$

Opseg pokreta šake nakon rehabilitacije na terapijskom uređaju Amadeo nešto je manji nego kod prvog mjerenja. Objašnjenje ovih rezultata nalazi se u neurofiziološkim mehanizmima kontrole pokreta pojedinog prsta kod pacijenata s problemima spastičnosti ramenog obruča. Ispitanici koji nemaju velik spazam mogu se njime koristiti za aktivne pokrete, ali najveći im problem predstavlja koordinacija pokreta. Statističke značajne razlike kod aktivnog pokreta vjerojatno nisu utvrđene zbog sinergističkog utjecaja spazma na pokret. ${ }^{10}$

Redukcija spazma provodi se u cilju poboljšanja raspona pokreta, aktivnosti i participacije pacijenata. Predstavlja velik problem u neurorehabilitacijskom procesu i često je glavni faktor koji otežava izvođenje selektivnih pokreta. ${ }^{11}$ Metoda koja se najčešće primjenjuje za procjenu spazma jest modificirana Ashworthova skala. Medijan spazma na početku rehabilitacije iznosio je 2,2 po modificiranoj Ashworthovoj skali, dok je nakon rehabilitacije spazam nešto veći, 3,0. Naglasak na povećanje opsega pokreta, čemu je usmjeren robotski terapijski uređaj Amadeo, vjerojatno bi imao bi veći učinak pri uspostavi aktivne kontrole spazma šake kada bi pacijenti bili u istom vremenskom intervalu.

Udio naših ispitanika kod kojih je smanjen tonus na kraju terapije bio je 8/16. Općepoznato je da na tonus utječu brojni okolni čimbenici te je evaluacija nije donijela statistički značajne rezultate.
Između moždanog udara naših ispitanika i početka rehabilitacije na robotskom terapijskom uređaju Amadeo u prosjeku su prošle dvije godine, što je umanjilo učinkovitost postupaka, a to je velik period u odnosu na paralelna istraživanja.

Nedostaci i ograničenja provedenog istraživanja ostavljaju mjesta daljnjem istraživanju. $U$ istraživačkom radu svakako treba uzeti u obzir druge moguće čimbenike odgovorne za razliku rezultata ispitanika, poput dobi i spola ispitanika, pokazatelja vrste, opsega, lokalizacije moždanog oštećenja, detaljnije pokazatelje psihičkog statusa ispitanika, pokazatelje utjecaja čimbenika životnog okruženja i obitelji ispitanika. Ova skupinu čini mali broj ispitanika i nedostatak kontrolne skupine, što je onemogućilo primjenu osjetljivijih metoda statističke obrade podataka pa bi u buduća istraživanja trebalo uključiti veći broj ispitanika.

Za selektivnije istraživanje utjecaja robotskoga terapijskog uređaja Amadeo na povećanje opsega pokreta i snage te smanjenje tonusa i spazma u šaci kod osoba nakon moždanog udara potrebno je duže razdoblje za praćenje ispitanika te bi se u budućim istraživanjima moglo usporediti s kombinacijom terapije u kući.

\section{Zaključak}

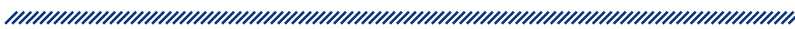

Robotski terapijski uređaj Amadeo omogućava bolja, objektivnija i brža mjerenja snage, opsega pokreta, tonusa i spazma pojedinog prsta koja se mogu primijeniti za klinička istraživanja i funkcionalnu evaluaciju pacijenta. Rezultati pojedinog pacijenta pohranjeni su u bazi podataka uređaja kako bi fizioterapeuti mogli objektivno pratiti svaku fazu rehabilitacijskog procesa. Primjenjuje se kao dodatak klasičnoj neurorehabilitaciji i kao dopuna radnoj terapiji pod educiranim medicinskim nadzorom. Velik broj istraživanja dokazuje pozitivne učinke robotike na povećanje opsega pokreta i snage gornjih ekstremiteta.

Prednosti rehabilitacije robotikom ne odnose se samo na lokomotorni sustav, poput povećanja opsega pokreta, snage, nego i poboljšanje pažnje, motivacije i spretnosti temeljeno na audiovizualnim podražajima, što pospješuje pacijentov proces neurorehabilitacije.

Istraživanje i činjenica da specijalisti fizijatrijske medicine sve češće upućuju pacijente na terapiju robotikom po- 
kazuje da bi se terapija robotskim uređajem Amadeo trebala primjenjivati kao jedna od glavnih metoda tretmana pacijenata nakon moždanog udara. Provedeno istraživanje može pridonijeti važnosti uključivanju robotike u pravodoban početak fizioterapije kod neuroloških bolesnika. Stoga je važna informiranost osoba nakon moždanog udara o prednosti neurorehabilitaciji robotikom.

Veliku ulogu u rehabilitaciji nakon moždanog udara ima edukacija pacijenata i njegove obitelji kako bi održali kvalitetu života kroz svakodnevne aktivnosti. Edukacija omogućava većini pacijenata povratak na posao ili profesionalno educiranje za promjenu posla odnosno za poslove koje je osoba nakon moždanog udara sposobna izvršavati. Također je nužna timska suradnja fizioterapeuta, radnog terapeuta, neurologa, specijalista fizijatrijske medicine i stručnjaka drugih specijalnosti.

Neurorehabilitacija robotikom trebala bi biti veza između različitih fizioterapeutskih tehnika i srodnih područja prema budućim perspektivama rehabilitacije koju pacijenti sve više prihvaćaju uzimajući u obzir pozitivne rezultate brojnih istraživanja. Premda su mišljenja o upotrebi suvremenih tehnologija u medicini (rehabilitaciji) podijeljena, mišljenja smo i vjerujemo, kako je u ovom istraživanju i potvrđeno, da suvremene tehnologije uz pravilnu primjenu i poštivanje etičkih normi uistinu mogu biti od pomoći suvremenom čovjeku. Svakako bi trebalo izbjegavati bilo kakve površne ocjene u pogledu na umjetnu inteligenciju, ${ }^{12}$ bilo da je riječ o pozitivnim bilo o negativnim stavovima. $U$ služenju robotikom otvaraju se i mnoga pitanja odgovornosti ${ }^{13}$ na koja će trebati davati odgovore i o kojima je već trebalo početi misliti kako nas ne bi zaskočila i iznenadila.

\section{Referencije}

1. Oljača A, Schnurrer-Luke-Vrbanić T, Avancini-Dobrović V, Kraguljac D. Neurorehabilitacija u pacijenata nakon preboljenog moždanog udara. Medicina fluminensis. 2016; 52(2): 165-175. Dostupno na: https://hrcak.srce. hr/158497 (pristupljeno 13.8.2018.).

2. Tomaj M, Marinčić M. Mastikoterapija i bioetičke perspektive u liječenju pacijenata nakon moždanog udara. Zdravstveni časopis Rauche. 2017; 8: 81-87. Dostupno na: https://www.bib.irb.hr/890747 (pristupljeno 15.8.2018.).

3. Houra K, Perković D, Hudetz D, Radić A, Rod E, Borić I, Prpić Vučković R, Skok I, Granec D, Mikula I, Skelin A, Lauc
G, Škaro V, Primorac D. Personalizirana medicina u modernoj radiologiji, neurologiji, neurokirurgiji, ortopediji, anesteziologiji, fizikalnoj medicini i rehabilitaciji te pedijatriji: Model Specijalne bolnice Sv. Katarina. Paediatria Croatica 2016; 60: 1-17. Dostupno na: https://www.bib. irb.hr/807964 (pristupljeno 4.10.2018.).

4. Lipozenčić J. Personalizirana medicina u Hrvatskoj. Medix. 2013; 104/105: 28-30. Dostupno na: https://hrcak. srce.hr/file/157110 (pristupljeno 4.10.2018.).

5. Europski parlament. Usvojeni tekstovi: Pravila građanskog prava o robotici. Rezolucija Europskog parlamenta od 16. veljače 2017. s preporukama Komisiji o pravilima građanskog prava o robotici (2015/2103(INL)). Dostupno na: http://www.europarl.europa.eu/sides/ getDoc.do?pubRef=-//EP//NONSGML+TA+P8-TA-20170051+0+DOC+PDF+V0//HR (pristupljeno 14.5.2018.).

6. Nikolić G. Medicina - perspektivno područje primjene robotike. Polytechnic \& design. 2016; 4(3): 208-224. Dostupno na: https://hrcak.srce.hr/191499 (pristupljeno 18.8.2018.).

7. Karabegović I, Karabegović E, Husak E. Primjena servisnih robota u rehabilitaciji i pomoći bolesnicima. Medicina Fluminensis. 2013; 49(2): 167-174. Dostupno na: https://hrcak.srce.hr/103482 (pristupljeno 20.8.2018.).

8. Amadeo Gebrauchsanweisung/User manual Tyromotion. Srpanj 2016. Dostupno na: https://tyromotion.com/ wp-content/uploads/2016/07/AMADEO_R7_Manual_ EN.pdf (pristupljeno 11.8.2018.).

9. Pinter D, Pegritz S, Pargfrieder C, Reiter G, Wurm W, Gattringer T, Linderl-Madrutter R, Neuper C, Fazekas F, Grieshofer $\mathrm{P}$, Enzinger C. Exploratory Study on the Effects of a Robotic Hand Rehabilitation Device on Changes in Grip Strength and Brain Activity after Stroke. Topics in Stroke Rehabilitation. 2013; 20 (4): 308-316. Dostupno na: https://www. researchgate.net/publication/253335994/download (pristupljeno 23.8.2018.).

10. Maček Z, Klaić I. Učinci specifične mobilizacije spastičnih mišića ramenog obruča na opseg i kontrolu pokreta ramena. Physiotherapia Croatica. 2010; 11 (2): 9-16. Dostupno na: https://www.bib.irb.hr/698816 (pristupljeno 8.9.2018.).

11. Bakran Ž, Baniček I, Varjačić M, Šoša I. Usporedba učinkovitosti fizioterapije i kombinacije fizioterapije s botulin toksinom A. Physiotherapia Croatica. 2010; 11 (2): 27-30. Dostupno na: https://www.bib.irb.hr/593736 (pristupljeno 12.9.2018.).

12. Kovač J. Ljudska mudrost vs. umjetna inteligencija. IRT 3000 Adria. 2017; 41: 202-208. Dostupno na: https://www. google.hr/url?sa=t\&rct=j\&q=\&esrc=s\&source=web\&cd=1\& cad=rja\&uact=8\&ved=2ahUKEwiUqvWsn4TeAhXilYsKHe9R BcUQFjAAegQICRAC\&url=https\%3A\%2F\%2Fwww.irt3000. com\%2Fmma\%2F-\%2F2017122007455321\%2F\&usg=AOv Vaw0EBVabOaRYAFcJV6rN51VJ (pristupljeno 2.10.2018.).

13. Truschzinski M. Ethische Herausforderungen in der Robotik. Conference Paper. 2017; 320-322. Dostupno na: https://www.researchgate.net/publication/319546860_ Ethische_Herausforderungen_in_der_Robotik (pristupljeno 18.9.2018.). 


\section{EFFECT OF USING AMADEO IN HAND NEUROREHABILITATION OF PERSONS AFTER A STROKE}

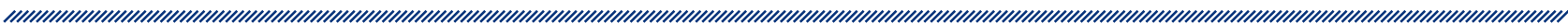

1 Mark Tomaj

2 Mile Marinčić

1 Polyclinic Glavić Zagreb

2 College Ivanić - Grad

\section{Abstract}

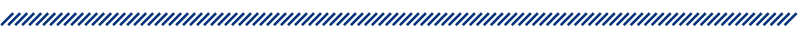

INTRODUCTION: Stroke is an illness of the brain structures, resulting in a reduced possibility of movement, disturbance in motion and walking coordination. It is the third cause of death in the world, and the second cause of mortality in Croatia. People who have overcome stroke can have severe injuries, limitations of movement and perception problems. Although traditional rehabilitation methods are most commonly used in rehabilitation of stroke patients, neurorehabilitation today uses robotics more increasingly. Robotics in neurorehabilitation of persons after a stroke has its own place in the rehabilitation protocol. The aim of the neurorobotics is to support the rehabilitation of the upper and lower extremities with the purpose of recovering the damaged motor faculites to assist patients in carrying out their daily activities. This research has shown the effect of Amadeo robotic therapeutic device on the rehabilitation of the hand function. The main goal of the Amadeo robotic therapy device is a focused workout achievement with a constant increase in intensity and repetition rate. The research will also warn about the possible ethical problems encountered by mod- ern medicine, especially when it comes to the use of modern technology in rehabilitation processes. This is a rethink of ethical review in the work and raises open questions for further research in the future.

AIM OF STUDY: Investigate the effect of the Amadeo robotic therapy device on increasing the range of motion and strength, reducing tonus and spasms in people after the stroke.

METHODS: Measurement at the beginning and end of robotic therapeutic device Amadeo were performed to check the performance. Measurements are related to the range of motion, strength, tone and spasm on the modified Asworth scale.

RESULTS AND CONCLUSIONS: The results of the strength measurement of the hand showed a statistically significant difference between the measurement result at the beginning and end of the therapy. Robotic therapy device Amadeo is safe and often used for clinical research.

Keywords: stroke, neurorehabilitation, robotics, ethics, robotic therapy device Amadeo. 